\title{
Design of an intelligent system for controlling and balancing renewable energy flows in an autonomous micro-grid
}

\author{
K. R. Assilevi ${ }^{1}$, A.S. Ajavon ${ }^{1}$, and K. H. Adjallah ${ }^{2}$ \\ ${ }^{1}$ CERME, Université de Lomé, 01 BP 1515 Lomé 1, Lomé, Togo \\ ${ }^{2}$ LCOMS EA-7306, Université de Lorraine, 57078, Metz, France
}

\begin{abstract}
Pooling different renewable energy sources (hydrogen, solar, wind, geothermal, etc.) enables developing a standalone energy micro-grid. The energy flows from these various sources are neither constant nor equivalent. Therefore, control and balancing mechanisms should be established for optimal energy utilization through an intelligent system based on interconnected microcontrollers networked with sensors. Our contribution addresses this issue by proposing an original architecture of an intelligent and distributed control system based on a sensor network and a strategy to share the electric power through the micro-grid. In our work we consider a micro-grid powered by sources of wind turbine, pv panels and battery which energy flows are controlled and balanced through our system depending on power demand of the loads. Alternating Current (AC) bus and Direct Current (DC) bus are tied together by an inverter. A set of microcontroller-sensor-actuators (which we named S.A.D for Sensor/Actuator Device) are deployed at strategic points in the micro-grid providing constantly data from power generated and consumed, equipment health and status. A control algorithm developed in relation to a network control strategy is implemented by combining the performance different microcontroller boards. Relying on existing literature works, a review of solution approaches to the challenging problem, of the power flows balancing between the different energy sources and storage batteries embedding appropriate IoT technologies and exploiting energy big-data platforms, is presented.
\end{abstract}

Keywords: Micro-grid, sensor network, flow balancing, microcontroller, intelligent system, IoT, $5 \mathrm{G}$

\section{Introduction}

Renewable energy micro-grids have proven to be an excellent alternative in terms of meeting energy needs around the world and especially in Africa where the traditional grid is showing its limits in providing electricity [1], especially in hard-to-reach areas [2],[3].

Depending of energy needs [4], different architectures are implemented [5] taking into account the available renewables energies.

Depending on the context, some micro-grids are deployed by pooling available energy sources. These micro-grids consisting of various types of the micro-generators as distributed generator [6] (wind turbine, photovoltaic (PV) array, fuel cells, diesel generator, and wave generator, CHP, ...), [7] local storage elements (flywheel, energy capacitors and batteries) and loads. Storage devices play a key role in micro-grid control, reliability and stability.

So, with these different types of energy sources, the micro-grid architecture consists in an alternating current (hybrid AC) micro-grid with a direct current (DC) micro-grid, tied 
together by a bidirectional AC/DC converter [8]. Distributed generators can be connected to the AC or to the DC feeder. This architecture combines the advantages of the AC and DC micro-grid.

Since, the energy flows from these various sources are neither constant nor equivalent. control and balancing mechanisms [9], [10], [11] should be established for optimal energy utilization through an intelligent system based on interconnected microcontrollers [12] networked with sensors [13].

Our work was carried out on a micro-grid installed in a peripheral area of Lomé in Togo (West Africa), in a district where wind and sun conditions favor the production of wind and solar energy.

The contributions in our work are as follows: (1) Design of an improved system architecture for controlling and balancing energy flows. (2) Development of a strategy for controlling and balancing energy flows. (3) Development and implementation of a responsive, intelligent algorithm embedded on microcontrollers installed at strategic locations in the micro-grid. (4) Connection of the system to an loT platform via 5G network to monitor, analyze, and process new data resulting from the algorithm's implementation.

\section{Related work}

Recent work in micro-grid focused on the management of various renewable energies sources. Giorgio Graditi et al. [14] developed a heuristic-based formulation of shiftable loads; Amin et al. [15] formulated a model predictive control; Lei Zhang et al. [16] projected twoscale dynamic programming strategy and subsequently Ashabani et al. [17] proposed nonlinear control for energy management in micro-grid. In [18], Jinsung Byun et al. envisioned intelligent cloud home energy management system (iCHEMS), in which the appliances shedding is fared in accordance with the assigned priority considering the renewable energy capacity.

K. Venkatraman et al. [19] developed a micro-grid controller integrating the output from multiple types of renewable energy conversion systems, namely, wind and solar along with diesel generator as well as battery storage with source and load control features using Field Programmable Gate Arrays.

Another renewables energies sources system energy management is done by using $\mathrm{PI}$ controller in [20], [21],[22],[23]. Somnath Das et al. in [10], implemented a control strategy with fuzzy logic controller for smoothing of the power fluctuation and at the same time to maintain the battery state of charge with in allowable limits.

Betha et al. [24] combined an autonomous PV and a wind turbine using a DC bus, and the generated output power from the system is fed to all connected loads, while the extra power is injected into the electric grid.

Hajizadeh and Aliakbar Golkar [25] introduced an approach for active power sharing in a hybrid fuel cell/battery power source in order to improve the system's efficiency and battery's lifetime with an acceptable load.

Elmouatamind et al. [26] introduced a micro-grid system platform for efficient integration and management of renewable energy sources and storage devices.

Hangaragi [27] proposed a hybrid PV-wind system, which provides a sophisticated integration of the wind turbine and solar PV, in order to extract the optimum energy from the two sources, PV and wind.

In [28] a microcontroller network is implemented, interconnected to micro-grid sources. In this architecture, microcontrollers are connected to key elements of the micro-grid: collectors, energy storage devices and the energy management system among others. 
These microcontrollers are the entry point to the sensor network. They are responsible for collecting the data and information produced at the level of the sensors, and for sending them via a VPN (Virtual Private Network) connection to the gateways. The latter proceed to transfer the data after the authentication and authorization procedures. These data, which are encrypted, are then conveyed to the heart of the sensor network for analysis and exploitation.

In our work, we used the performance of microcontroller boards, arduino and raspberry in order not only to make the system for controlling and balancing energy flows more efficient but also in case of addition of new components in the network and implementation of algorithms in arduino and python programming language for a dialogue between the platform and the cloud.

\section{Micro-grid architecture}

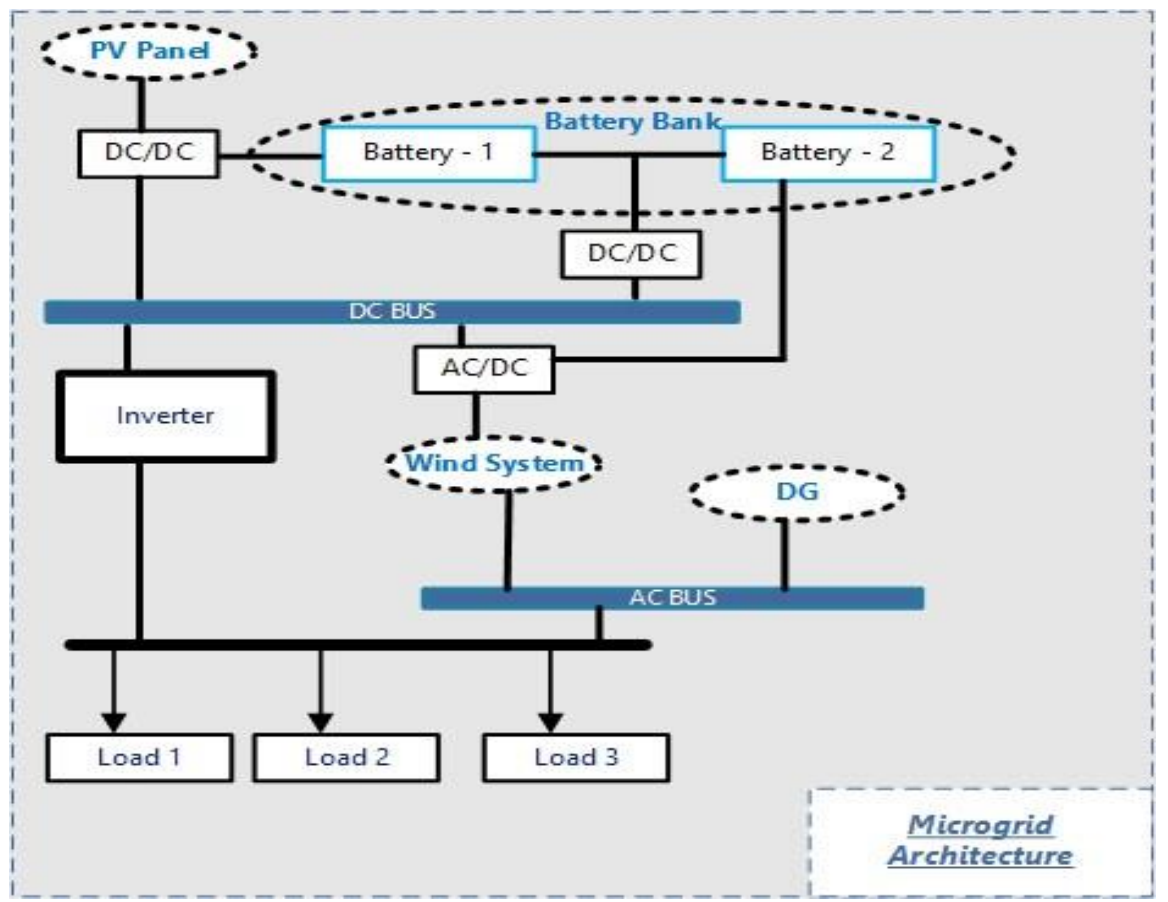

Figure 1. Micro-grid architecture

The micro-grid, subject of our study pools four energy sources. The priorities come from solar panels and wind turbines. The energy generated by these two sources is each stored in a specific battery. The two batteries, combined constitute a battery bank which is the third source of energy. This source is used in the event of a shortfall in solar and wind power generation. The fourth source of energy which is used upon in the ultimate event is the diesel generator. The architecture of the micro-grid is shown in Figure 1. The energy sources of this micro-grid are used to meet the needs of three different loads.

\section{Proposed system and strategy}

The proposed system interconnects with the existing micro-grid through specific nodes that we named S.A.D (for Sensor / Actuator Device). It is nothing more than a set of sensors and actuators linked to a microcontroller.

The S.A.D are placed in specific places depending on what we want to monitor and control. The S.A.D. are linked to a control and management center thus forming a network of 
microcontrollers. This control center is connected to the cloud to which it sends data for monitoring needs and which is also stored in a database which is analyzed for future uses.

\section{A. Proposed architecture}

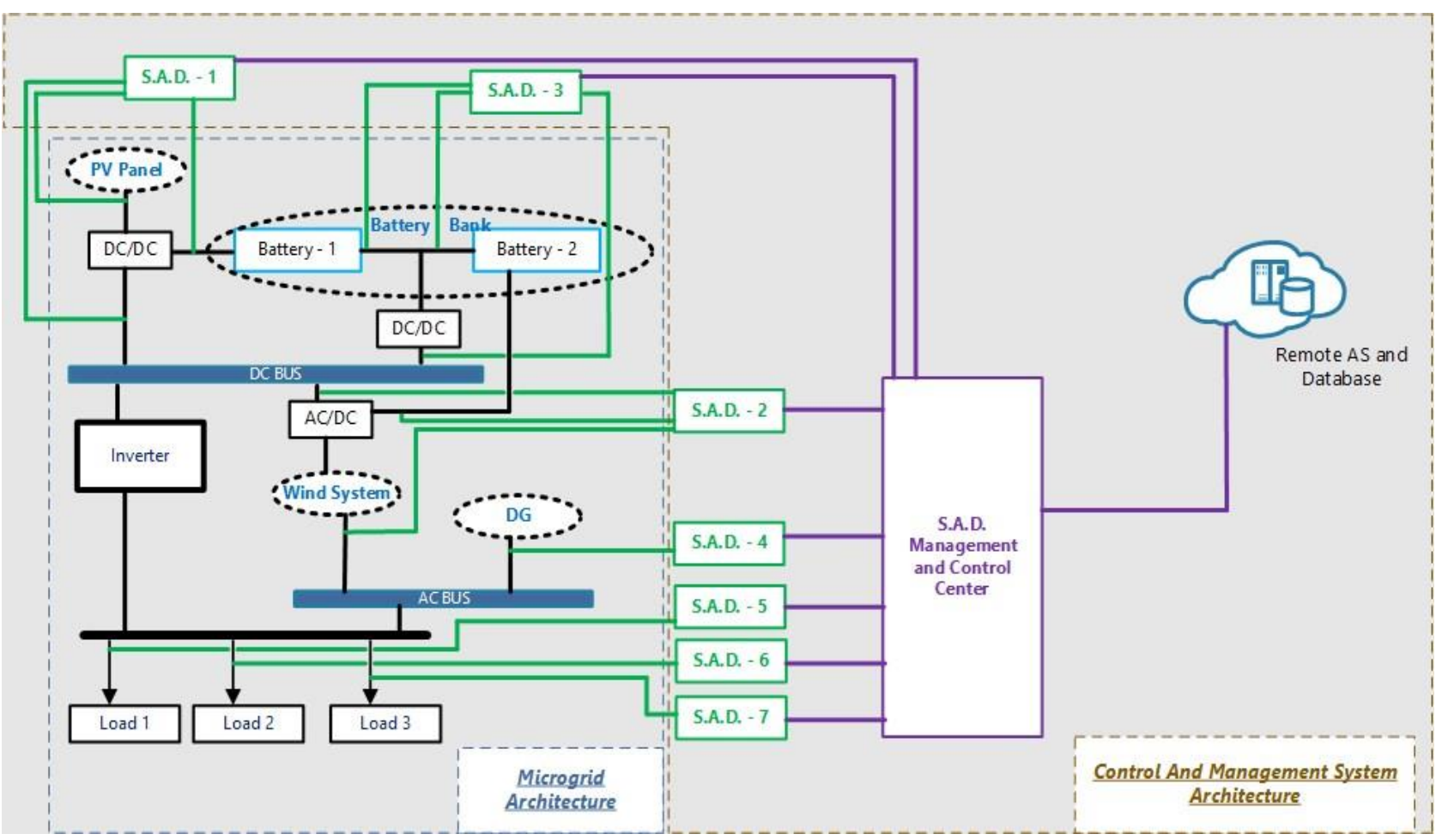

Figure 2. Control and management system architecture

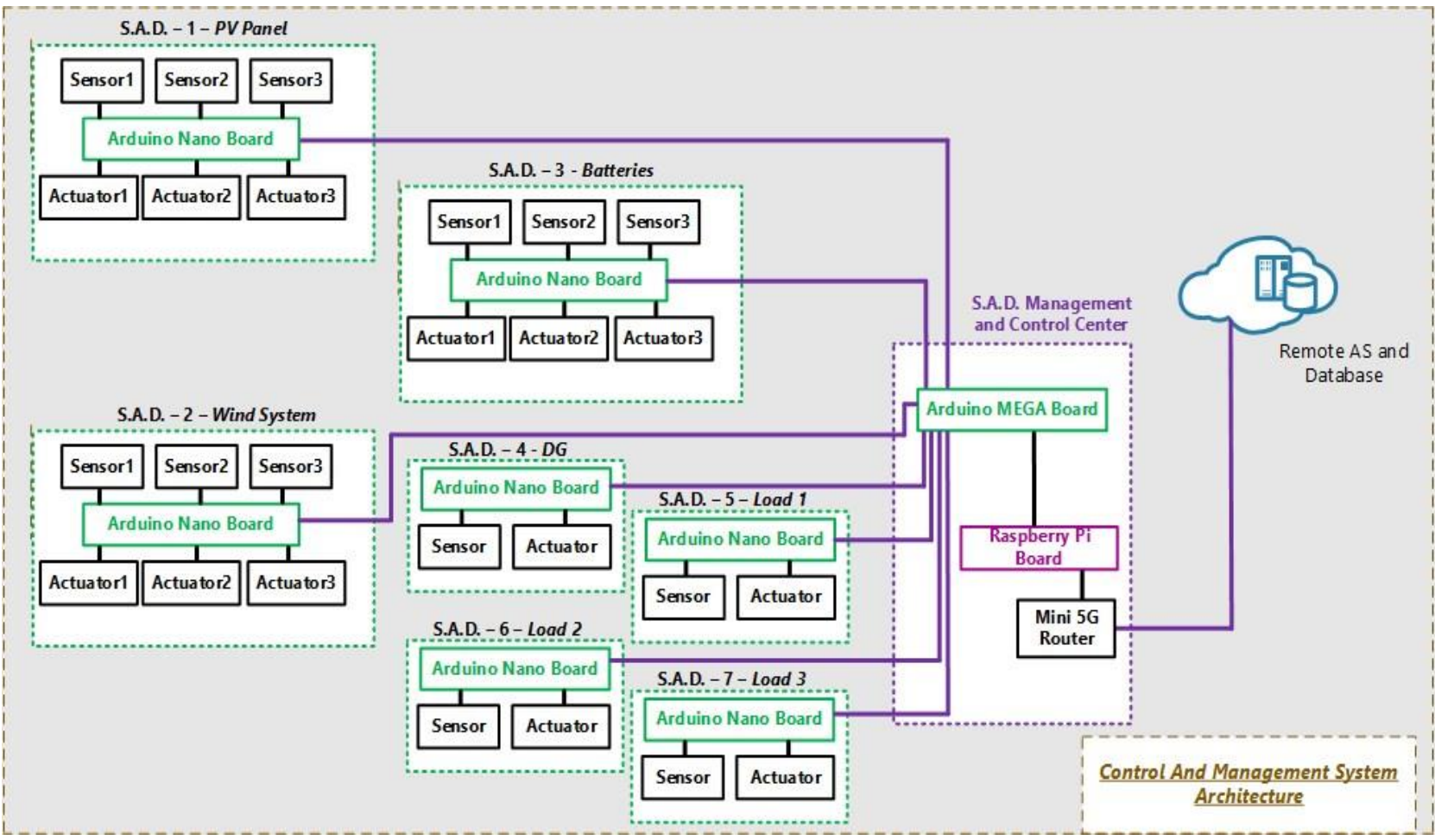

Figure 3. Control and management system architecture details 
Figure 2. shows us the general architecture of the micro-grid connected to the network of microcontrollers formed by the S.A.D.. Thus presenting the architecture of the control and management system of energy flows.

The Sensor / Actuator association for each S.A.D depends on the source or the load to be controlled; therefore varying the number of elements to be connected to the microcontroller as shown in Figure 3.

The microcontroller network as well as the control strategy are shown in the following sections.

\section{B. Microcontroller network}

\section{Sensor / Actuator Device (S.A.D.)}

Figure 4 is an internal image of the S.A.D showing the connections of the microcontroller to the sensors on the one hand and to the actuators on the other hand.

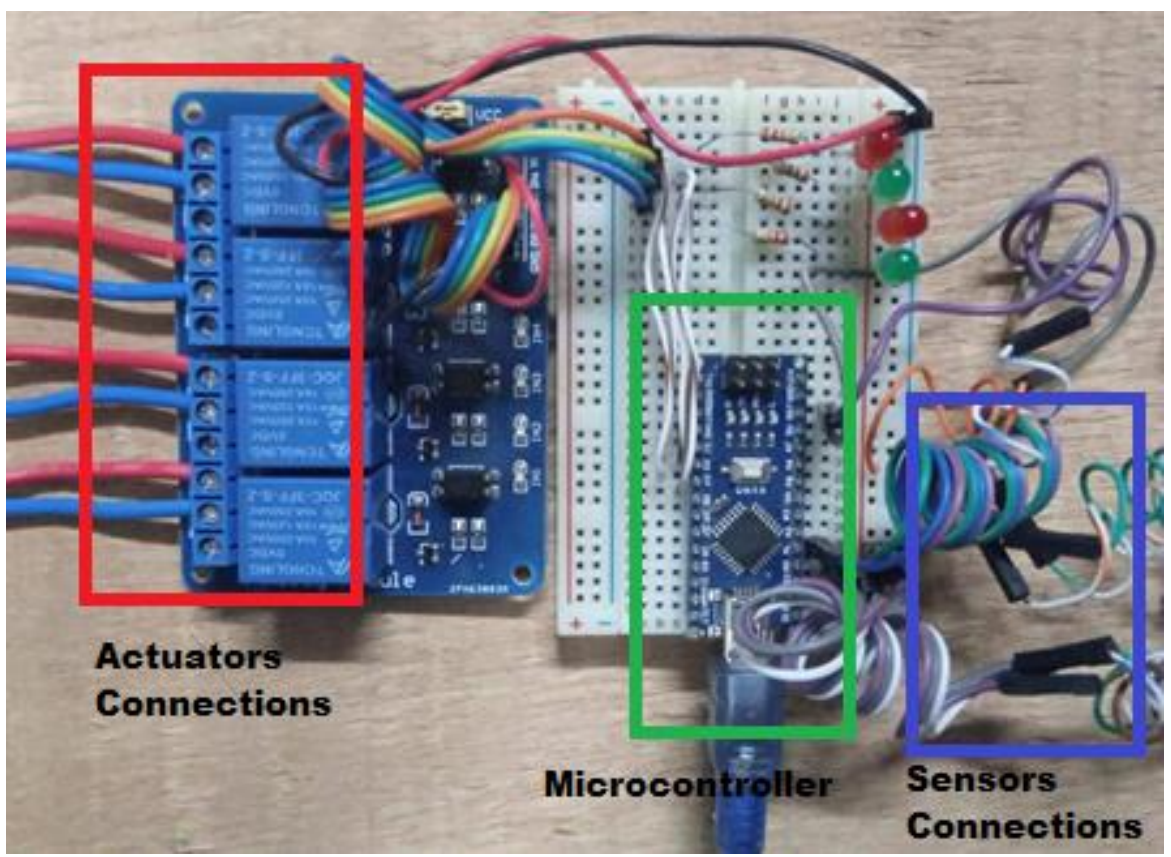

Figure 4. Sensor / Actuator Device

Each S.A.D in the network has a specific role to play depending on its location in the network. Table 1 summarizes the roles of each sensor and actuator of each S.A.D.

Table 1. S.A.D roles in the network

\begin{tabular}{|l|l|l|l|}
\hline$N^{\circ}$ S.A.D & $\begin{array}{c}\text { Source / } \\
\text { Load }\end{array}$ & \multicolumn{1}{|c|}{$\begin{array}{c}\text { Sensor } / \\
\text { Actuator }\end{array}$} & \multicolumn{1}{c|}{ Roles } \\
\hline \multirow{4}{*}{1} & Sensor 1 & Sense power from PV pannel \\
\cline { 3 - 4 } & Sensor 2 & $\begin{array}{l}\text { Sense voltage and current between DC/DC } \\
\text { converter and DC Bus }\end{array}$ \\
\cline { 3 - 4 } & Pannel & Sensor 3 & $\begin{array}{l}\text { Sense voltage and current between DC/DC } \\
\text { converter and Battery 1 }\end{array}$ \\
\cline { 3 - 4 } & Actuator 1 & $\begin{array}{l}\text { Control link between PV panel and DC/DC } \\
\text { converter }\end{array}$ \\
\cline { 3 - 4 } & Actuator 2 & $\begin{array}{l}\text { Control link between DC/DC converter and } \\
\text { AC Bus }\end{array}$ \\
\hline
\end{tabular}




\begin{tabular}{|c|c|c|c|}
\hline & & Actuator 3 & $\begin{array}{l}\text { Control link between DC/DC converter and } \\
\text { Battery } 1\end{array}$ \\
\hline \multirow{6}{*}{2} & \multirow{6}{*}{$\begin{array}{l}\text { Wind } \\
\text { Turbine }\end{array}$} & Sensor 1 & Sense power from Wind turbine \\
\hline & & Sensor 2 & $\begin{array}{l}\text { Sense voltage and current between AC/DC } \\
\text { converter and DC Bus }\end{array}$ \\
\hline & & Sensor 3 & $\begin{array}{l}\text { Sense voltage and current between AC/DC } \\
\text { converter and Battery } 2\end{array}$ \\
\hline & & Actuator 1 & $\begin{array}{l}\text { Control link between Wind turbine and AC } \\
\text { Bus }\end{array}$ \\
\hline & & Actuator 2 & $\begin{array}{l}\text { Control link between AC/DC converter and } \\
\text { DC Bus }\end{array}$ \\
\hline & & Actuator 3 & $\begin{array}{l}\text { Control link between AC/DC converter and } \\
\text { Battery } 2\end{array}$ \\
\hline \multirow{6}{*}{3} & \multirow{6}{*}{ Battery } & Sensor 1 & Sense voltage and current from Battery 1 \\
\hline & & Sensor 2 & Sense voltage and current from Battery 2 \\
\hline & & Sensor 3 & $\begin{array}{l}\text { Sense voltage and current between } \mathrm{DC} / \mathrm{DC} \\
\text { converter and DC Bus }\end{array}$ \\
\hline & & Actuator 1 & Control flow from Battery 1 to battery bank \\
\hline & & Actuator 2 & Control flow from Battery 2 to battery bank \\
\hline & & Actuator 3 & $\begin{array}{l}\text { Control link between DC/DC converter and } \\
\text { DC Bus }\end{array}$ \\
\hline \multirow[b]{2}{*}{4} & \multirow{2}{*}{$\begin{array}{l}\text { Diesel } \\
\text { Generator }\end{array}$} & Sensor & Sense power from Diesel Generator \\
\hline & & Actuator & $\begin{array}{l}\text { Control link between Diesel Generator and } \\
\text { AC Bus }\end{array}$ \\
\hline \multirow{2}{*}{5} & \multirow{2}{*}{ Load 1} & Sensor & Sense Load 1 voltage and current \\
\hline & & Actuator & Switch ON/OFF Load 1 \\
\hline \multirow{2}{*}{6} & \multirow{2}{*}{ Load 2} & Sensor & Sense Load 2 voltage and current \\
\hline & & Actuator & Switch ON/OFF Load 2 \\
\hline \multirow{2}{*}{7} & \multirow{2}{*}{ Load 3} & Sensor & Sense Load 3 voltage and current \\
\hline & & Actuator & Switch ON/OFF Load 3 \\
\hline
\end{tabular}

2. S.A.D. Management and Control Center

The S.A.D. Management and Control Center consists of an Arduino MEGA board to which all the S.A.D. of the network are connected. It exchanges data with the raspberry board which is connected to the cloud through a $5 \mathrm{G}$ mini router as shown in Figure 5. 


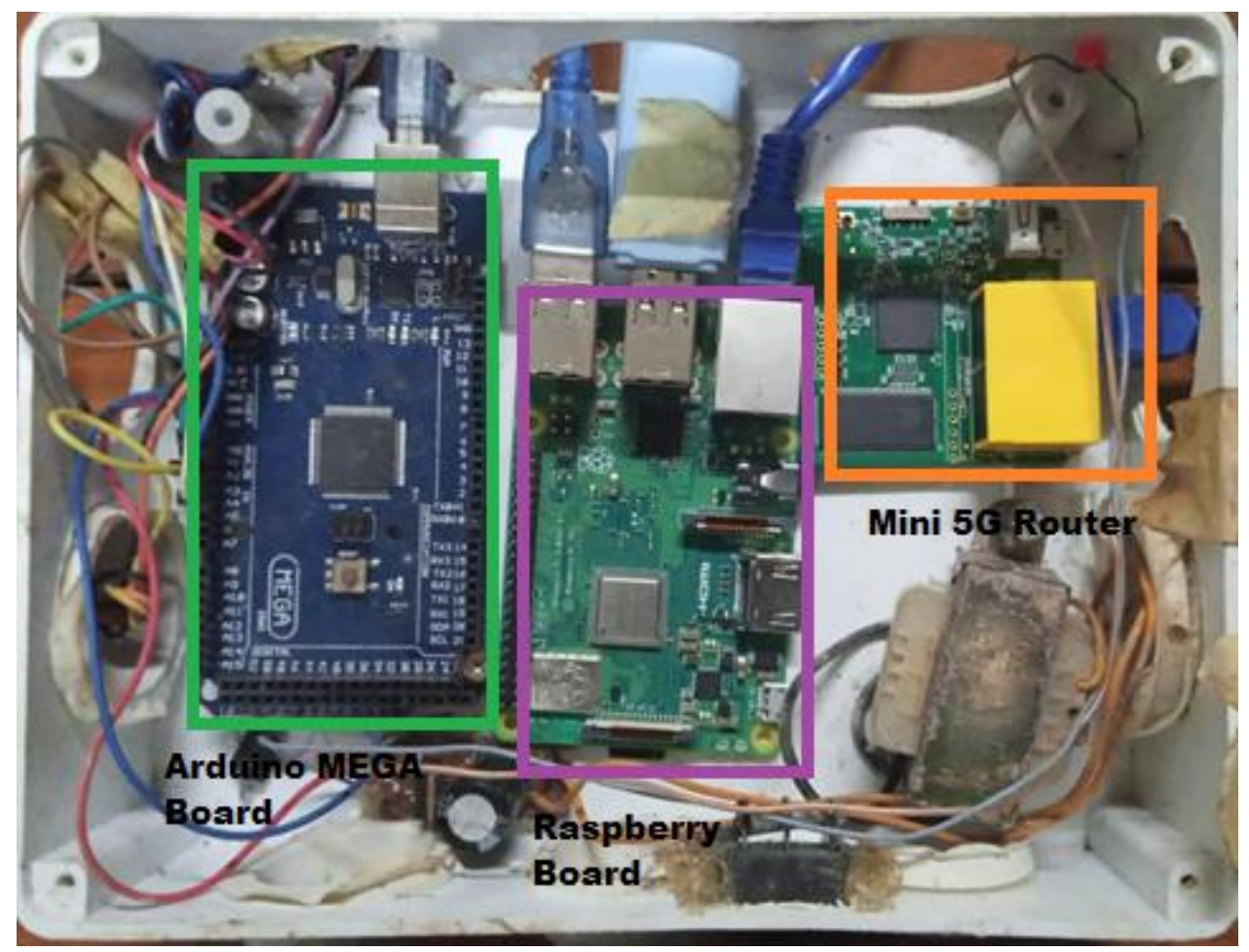

Figure 5. S.A.D. Management and Control Center

\section{Flows control strategy}

The S.A.D senses the flows generated and calculates the powers of energy supplied by the sources on the one hand, and the powers of energy required by the loads on the other hand.

These data are the inputs for the strategy of control and balancing of energy flows in the micro-grid.

The strategy is summarized as follows:

First, the powers generated by the sources and calculated are compared to the powers of the loads:

$\mathrm{P}_{\text {solar }}$ : PV pannel power

$\mathrm{P}_{\text {wind }}$ : Wind power

$P_{D G}$ : Diesel Generator power

$\mathrm{P}_{\mathrm{S}-\mathrm{W}}$ : Solar and Wind total generated power

The voltage at the output of the battery bank is also taken into account.

$\mathrm{V}_{\text {bat }}$ : Battery Bank Voltage

$\mathrm{V}_{\text {bat-min }}$ : Minimum Battery Bank Voltage

$V_{\text {bat-max }}$ : Maximum Battery Bank Voltage

In principle, the power of each load is taken into account the total power is then calculated.

$\mathrm{P}_{\mathrm{L} 1}$ : Load 1 power

$\mathrm{P}_{\mathrm{L} 2}$ : Load 2 power 


\section{$\mathrm{P}_{\mathrm{L} 3}$ : Load 3 power \\ $\mathrm{P}_{\mathrm{L}}$ : Loads Total power}

At the initial state, powers are computed as follows:

$$
\begin{aligned}
& P_{L}=P_{L 1}+P_{L 2}+P_{L 3} \\
& P_{S-W}=P_{\text {solar }}+P_{\text {wind }}
\end{aligned}
$$

For the control flow balancing:

If $P_{L}>P_{S-W}$ then Check $V_{\text {bat }}$

If $V_{\text {bat }}>V_{\text {bat-min }}$ then switch ON link between DC/DC converter and DC Bus

If still $P_{L}>P_{S-w}$ and $V_{\text {bat }}=V_{\text {bat-min }}$ then switch OFF link between DC/DC converter and DC Bus and switch ON DG

If $P_{L} \geq P_{D G}$ then switch OFF Load 3

If still $P_{L} \geq P_{D G}$ then switch OFF Load 2

If $P_{\text {solar }}$ available and $V_{\text {bat }} \leq V_{\text {bat-min }}$ then swith $\mathrm{ON}$ link between DC/DC converter and Battery1

If still $V_{\text {bat }} \leq V_{\text {bat-min }}$ then check $P_{\text {wind }}$

If $P_{\text {wind }}$ available and $V_{\text {bat }} \leq V_{\text {bat-min }}$ then swith ON link between AC/DC converter and Battery2

If $V_{\text {bat }}>V_{\text {bat-min }}$ and $V_{\text {bat }} \leq V_{\text {bat-min }}$ then swith OFF link between DC/DC converter and Battery1 and swith OFF link between AC/DC converter and Battery 2

If $\mathrm{P}_{\mathrm{L}}<\mathrm{P}_{\mathrm{S}-\mathrm{W}}$ then switch OFF DG switch OFF Load 2 and OFF Load 3

This strategy is translated into an algorithm and implemented in a python script that runs on the raspberry board and arduino code on arduino board. The information is displayed on a monitoring interface accessible via the cloud.

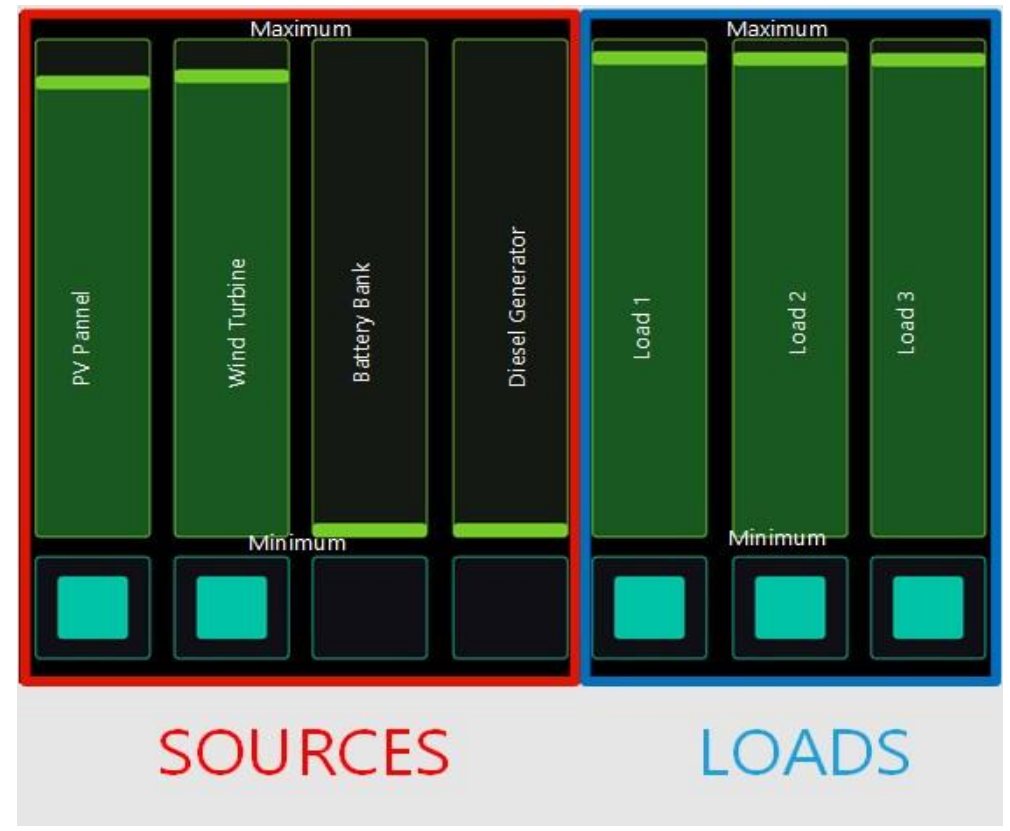

Figure 6. Monitoring Screen

On this screnn, $P_{\text {solar }}$ and $P_{\text {wind }}$ are at maximum of power. In this case, the generated power $\mathrm{P}_{\text {s-w }}$ can easily supply all of loads (Load 1, Load 2 and Load 3). So, Battery bank and Diesel Generator are not used. 


\section{Simulations and results}

Table 2. Sources informations

\begin{tabular}{|l|l|l|}
\hline $\mathbf{N}^{\circ}$ & Sources & Values (Voltage - Current - Power) \\
\hline 1 & PV Pannel & $137 \mathrm{~V}-5 \mathrm{~A}-685 \mathrm{~W}$ \\
\hline 2 & Wind Turbine & $126 \mathrm{~V}-14.5 \mathrm{~A}-1827 \mathrm{~W}$ \\
\hline 3 & Battery & $124 \mathrm{~V}-3 \mathrm{~A}$ \\
\hline 4 & Diesel Generator & $240 \quad-3.5 \mathrm{~A}-840 \mathrm{~W}$ \\
\hline
\end{tabular}

\section{A. Case 1: Wind Turbine OFF}

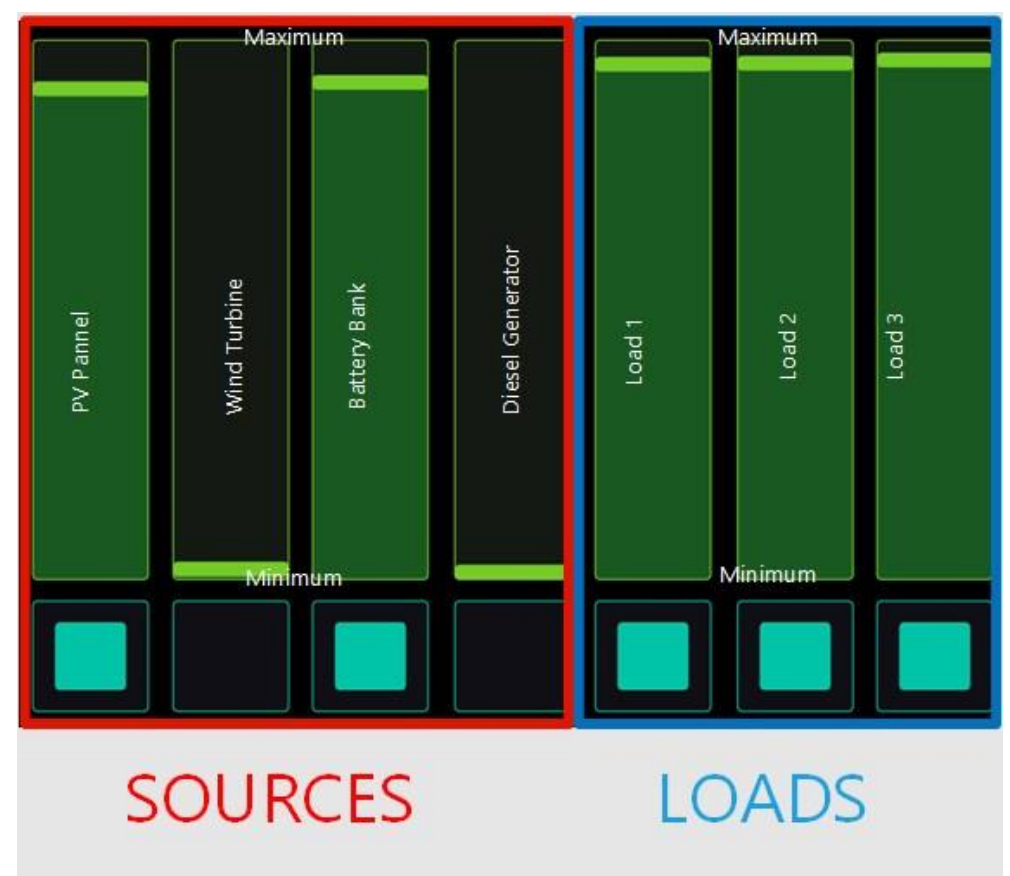

Figure 7. Monitoring Screen with PV panel Source and battery bank ON

The power generated is not sufficient to supply the loads, the battery bank is then used.

\section{B. Case 2: PV pannel OFF}

In this case, Wind turbine and PV panel are OFF and Battery voltage is not enough, so we swith ON Diesel Generator. 


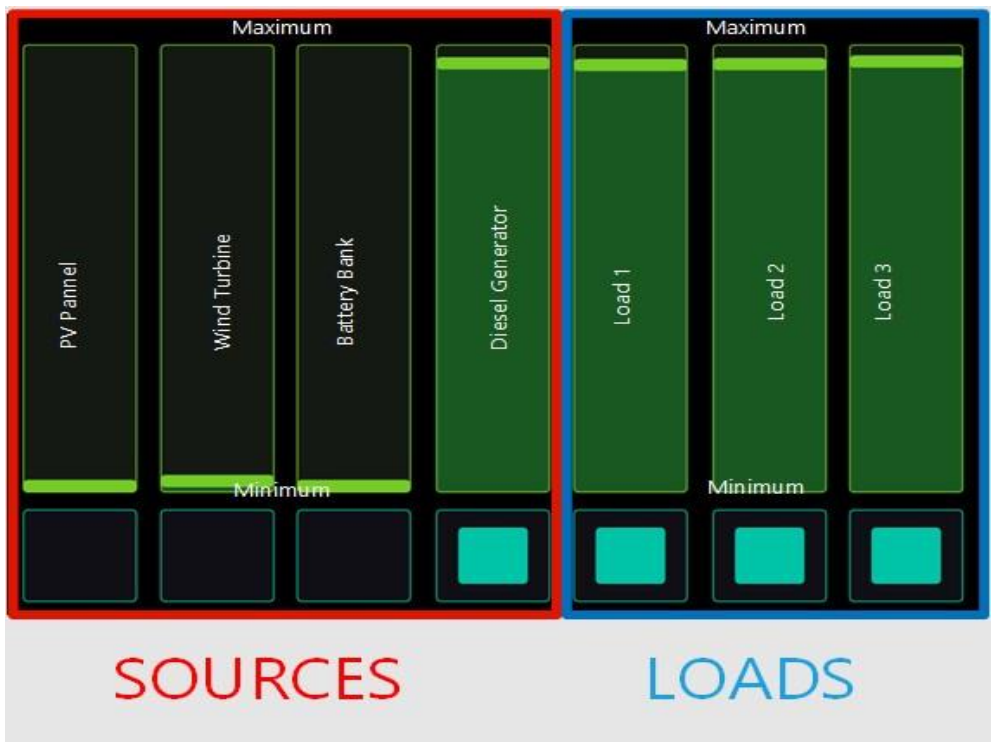

Figure 8. Monitoring Screen with DG ON and all loads ON

\section{Case 3: Diesel Generator ON}

With the DG being ON if the power generated does not cover the loads, we switch Load 3 OFF (Figure 9.) and if it is still not sufficient, we switch Load 2 off (Figure 10)

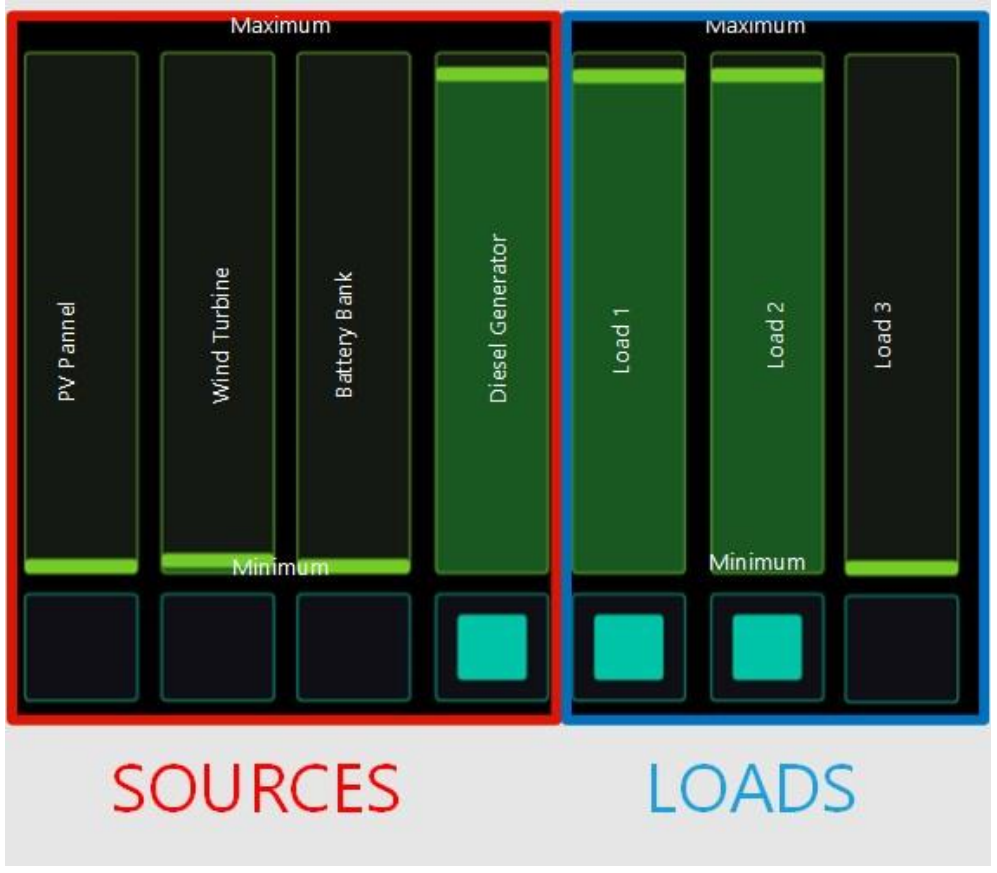

Figure 9. Monitoring Screen with DG ON and Load 3 OFF 


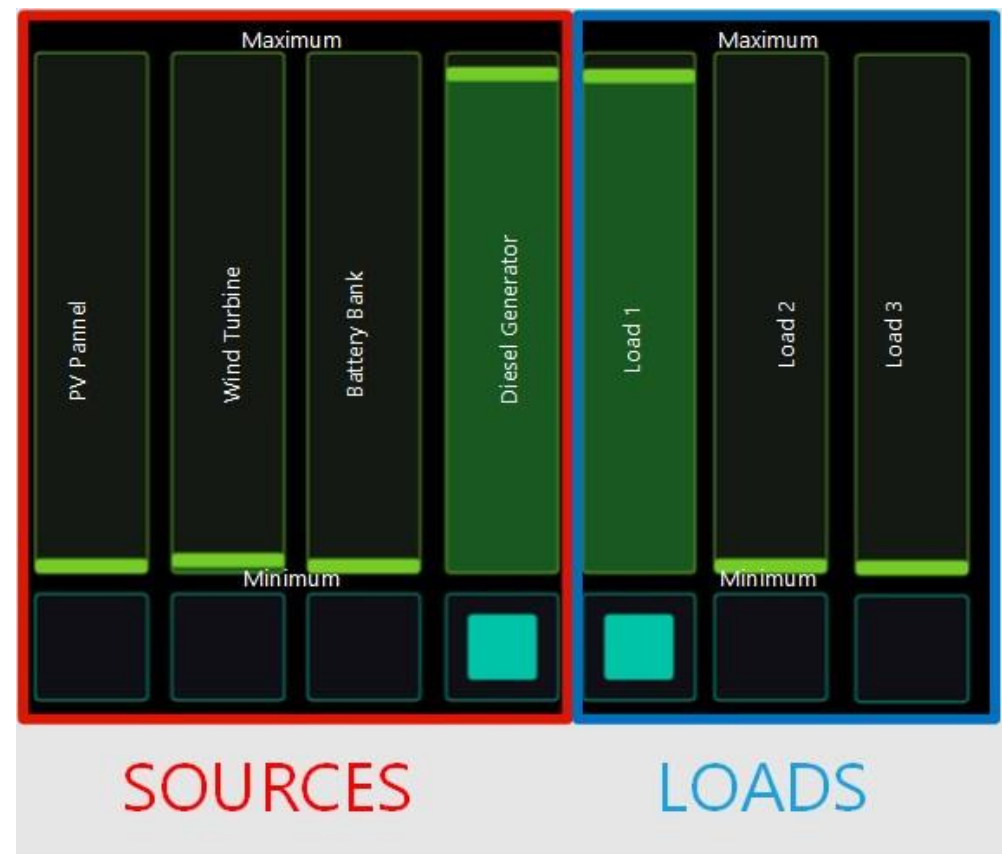

Figure 10. Monitoring Screen with DG ON and Load 2 and Load 3 OFF

\section{Conclusion}

In our work, we designed a microcontroller architecture interconnected to the renewable energy micro-grid.

A strategy is then implemented for the control and balancing of energy flows in the micro-grid.

The set of microcontroller-sensor-actuators (S.A.D) are deployed at strategic points in the micro-grid providing constantly data from power generated and consumed, equipment health and status.

The arduino and raspberry boards offer performance that collects data from the various equipment to which the sensors are connected. This data then travels to the cloud for analysis.

In the outlook, the power data will be analyzed and compared to the values collected over a given period, so as to detect the state of health of the equipment in order to take decisions in real time.

\section{References}

[1] Kpoda K, Ajavon A, Salami A, Kodjo K, Bedja K. Concise review of microgrid concepts and architecture. Journal de la Recherche Scientifique de l'Université de Lomé.

2018;4(4):613-631.

[2] Erbato TT, Hartkopf T. Smarter Micro Grid for energy solution to rural Ethiopia. IEEE PES ISGT (Innovative Smart Grid Technologies). 2012;:1-7.

https://doi.org/https://www.doi.org/10.1109/ISGT.2012.6175608

[3] Bekele G, Boneya G. Design of a Photovoltaic-Wind Hybrid Power Generation System for Ethiopian Remote Area. Energy Procedia. 2012;14:1760-1765.

https://doi.org/https://doi.org/10.1016/..egypro.2011.12.1164

[4] Dileep G. A survey on smart grid technologies and applications. Renew. Energy. 2020;. https://doi.org/https://doi.org/10.1016/j.renene.2019.08.092 
[5] Ustun TS, Ozansoy C, Zayegh A. Recent developments in microgrids and example cases around the world - A review. Energy Reviews. 2011; . https://doi.org/https://doi.org/10.1016/j.rser.2011.07.033

[6] Patrao I, Figueres E, Garcerá G, González-Medina R. Microgrid architectures for low voltage distributed generation. Renewable and Sustainable Energy Reviews. 2015;. https://doi.org/https://doi.org/10.1016/..rser.2014.11.054

[7] Hatziargyriou N. Microgrids: Architectures and Control. March 2014 Wiley-IEEE Press; 2014.

[8] Liu X, Wang P, Loh PC. A hybrid AC/DC microgrid and its coordination control. IEEE Trans. Smart Grid. 2011; . https://doi.org/https://www.doi.org/10.1109/TSG.2011.2116162

[9] Lo CH, Ansari N. Decentralized controls and communications for autonomous distribution networks in smart grid. IEEE Transactions on Smart Grid. 2013;4(1):66-77.

https://doi.org/https://www.doi.org/10.1109/TSG.2012.2228282

[10] Das S, Akella AK. Power flow control of PV-wind-battery Hybrid Renewable Energy Systems for stand-alone application. International Journal of Renewable Energy Research. 2018;8(1):36-43.

[11] Zhang L, Gari N, Hmurcik L. Energy management in a microgrid with distributed energy resources. Energy Convers. Manag. 2014;.

https://doi.org/https://doi.org/10.1016/j.enconman.2013.10.065

[12] Assilevi KR, Ajavon AS, Adjallah KH. Design of a virtual private network of intelligent microcontrollers for distributed control of an autonomous microgrid of renewable energy harvesters. To appear in the ICEASSM'2019 Proc., the 2nd Int. Conf. on Engineering, Applied Sciences and System Modeling (),. 2019.

[13] Majumder R, Bag G, Kim K. Power Sharing and Control in Distributed Generation with wireless sensor networks. IEEE Power and Energy Society General Meeting. 2012;. https://doi.org/https://www.doi.org/10.1109/PESGM.2012.6344966

[14] Graditi G, Di Silvestre ML, Gallea R, Riva Sanseverino E. Heuristic-Based Shiftable Loads Optimal Management in Smart Micro-Grids. IEEE Trans. Ind. Inf.. 2015;11((1)):271280. https://doi.org/https://www.doi.org/10.1109/TII.2014.2331000

[15] Amin , Bambang R, Rohman A, Dronkers K, Ortega R, Sasongko A. Energy Management of Fuel Cell/Battery/Supercapacitor Hybrid Power Sources Using Model Predictive Control. IEEE Trans. Ind. Inf.. 2014;10((4)):1992-2002. https://doi.org/https://www.doi.org/10.1109/TII.2014.2333873

[16] Zhang L, Li Y. Optimal Energy Management of Wind-Battery Hybrid Power System With TwoScale Dynamic Programming. IEEE Trans. Sustainable Energy. 2013;4((3)):765-773. https://doi.org/https://www.doi.org/10.1109/TSTE.2013.2246875

[17] Ashabani, S, Mohamed Y. General Interface for Power Management of Micro- Grids Using Nonlinear Cooperative Droop Control. IEEE Trans. Power Systems.

2013;28((3)):2929-294. https://doi.org/https://www.doi.org/10.1109/TPWRS.2013.2254729

[18] Byun J, Hong I, Park S. Intelligent cloud home energy management system using household appliance priority based scheduling based on prediction of renewable energy capability. IEEE Trans. Consumer Electronics. 2012;58((4)):1194- 1201. https://doi.org/https://www.doi.org/10.1109/TCE.2012.6414985

[19] Venkatraman K, Reddy BD, Selvan MP, Moorthi S, Kumaresan N, Gounden NA. Online condition monitoring and power management system for standalone micro-grid using FPGAs. IET Generation, Transmission and Distribution. 2016;10(15):3875-3884. https://doi.org/https://doi.org/10.1049/iet-gtd.2016.0445 
[20] Madaci B, Chenni R, Kurt E, Hemsas KE. Design and control of a stand-alone hybrid power system. International Journal of Hydrogen Energy. 2016;41(29):12485-12496. https://doi.org/https://doi.org/10.1049/iet-gtd.2016.0445

[21] Javad Mirazimi S, Fathi M. Analysis of hybrid wind/fuel cell/battery/diesel energy system under Alaska condition. ECTI-CON 2011 - 8th Electrical Engineering/ Electronics, Computer, Telecommunications and Information Technology (ECTI) Association of Thailand Conference 2011. 2011;::917-920. https://doi.org/10.1109/ECTICON.2011.5947990

[22] Jayalakshmi N, Gaonkar D, Nempu PB. Power Control of PV/Fuel Cell/Super capacitor Hybrid System for Stand-Alone Applications. International Journal of Renewable Energy Research. 2016;6(2):672-679.

[23] Malla S, Bhende C. Voltage control of stand-alone wind and solar energy system. Electrical Power and Energy Systems. 2014;56:361-373. https://doi.org/https://doi.org/10.1016/j.ijepes.2013.11.030

[24] Betha D, Satish M, Sahu S. Design and control of grid connected PV/wind hybrid system using 3 level VSC. IEEE 7th international advance computing conference..

https://doi.org/https://doi.org/10.1109/IACC.2017.0102

Hajizadeh A, Aliakbar Golkar M. Intelligent power management strategy of hybrid distributed generation system. Int J Elec Power. 2007;29:783-795.

https://doi.org/https://doi.org/10.1016/j.ijepes.2007.06.025

[26] Elmouatamid A, NaitMalek Y, Bakhouya M, Ouladsine R, Elkamoun N, Zine-Dine K, Khaidar M. An energy management platform for micro-grid systems using Internet of Things and Big-data technologies. Proceedings of the Institution of Mechanical Engineers. Part I: Journal of Systems and Control Engineering. 2019;233(7):904-917. https://doi.org/https://www.doi.org/10.1177/0959651819856251

[27] Hangaragi G. Recent Integration of a PV-wind energy system with enhanced efficiency. Indian J Sci Res. 2015;11((1)):72-78.

[28] Assilevi K, Ajavon A, Adjallah K. Design of a virtual private network of intelligent microcontrollers for distributed control of an autonomous micro-grid of renewable energy harvesters. in the ICEASSM'2019 Proc., the 2nd Int. Conf. on Engineering, Applied Sciences and System Modeling (), 2019. 